\title{
Effects of Rosmarinus Officinalis Plant Extract on Trichomonas Vaginalis Parasites and Candida albicans under Laboratory Conditions: An Experimental Study
}

Firas M.Alkashab ${ }^{1}$, Raya .Gh.Fathy ${ }^{2}$, Safaa.M.Sultan ${ }^{3}$

\{ Firasmb1977@gmail.com,2biologestraya@gmail.com,safaahawija@gmail.com\}

Mosul University ${ }^{1}$, Mosul University ${ }^{2}$ Northern Technical University ${ }^{3}$

\begin{abstract}
Antibiotics are used in the treatment of fungal infections as well as in the treatment of parasites, including trichomonas vaginalis, but these antibiotics such as Midazol, contain many side effects, which has led to the use of alternative medicine which is a treatment using plant extracts. The objective of this study was to examine the aqueous and alcoholic extract in the treatment of vaginal infections caused by the growth of Candida albicans as well as the trichomonas vaginalis parasite under laboratory conditions. Different concentrations of aqueous extract of rosemary were studied and their effect on the growth of this pathogenic microorganism was shown. The results showed that the aqueous and alcoholic extracts used in this research had an inhibitory effect on the growth of the parasite, trichomonas vaginalis in addition to Candida albicans, as the extracts of their aqueous and alcoholic types used with concentrations of $0.1,0.01,0.001$ for the alcoholic extract as well as 100, 200, 400 of the aqueous extract of the Rosmarinus Officinalis plant decreased expulsion with increased focus during the growth period.
\end{abstract}

Keywords: Candida albicans, trichomonas vaginals parasite, laboratory conditions, aqueous and alcoholic extracts

\section{Introduction}

Vaginal infections are among the most common diseases in women in the world. This type of disease is caused either by candidiasis or by a parasite called trichomonas vaginalis The protozoa unicellular parasite causes this parasite to emit an unpleasant odour from a woman's vagina and vaginal discharge. The pain and difficulty in urinating can also cause premature birth in pregnant women.

According to the Center for Disease Assessment and Prevention (CDC), there are about 7.4 million new cases worldwide every year [1] This contamination makes it the most common reproductive disease, and trichomoniasis seems to make women more easily infected by HIV, the virus that causes AIDS. Research has shown a link between trichomoniasis and two serious complications. Data indicates that trichomoniasis is associated with an increased risk of HIV transmission and also premature or low birth weight [2]. In men, this parasite usually does not cause symptoms, although the trichomonal infection may form an infection of HPV strain in males and lead to prostate cancer [3].

Rosmarinus officinalis. The rosemary plant (Lamiaceae) shown in fig. $\mathbf{1}$ is one of the main plants used in gardens because of its ability to be cut and formed.

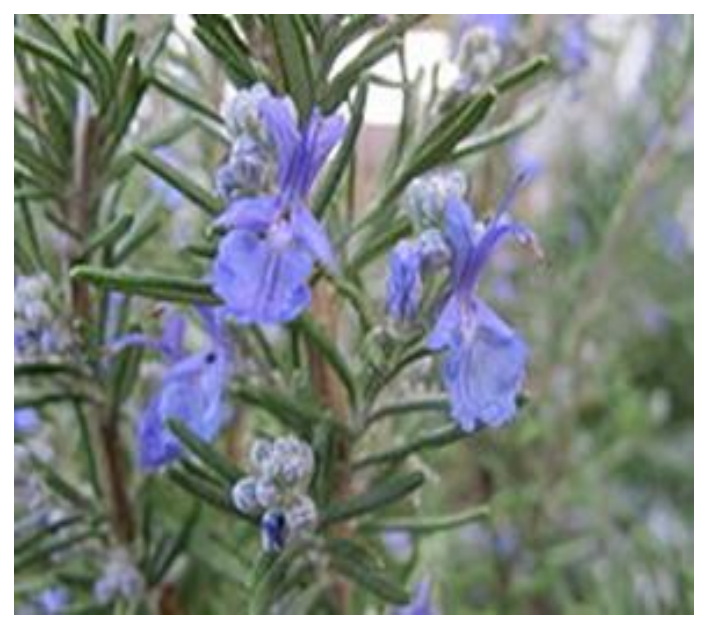

Figure 1. The rosemary plant (Lamiaceae) 
It is an evergreen shrub plant with a height of up to a meter and a half. It blooms from the beginning of April to the end of October and grows in the Mediterranean. As for the chemical aspect, the rosemary plant is rich in phenolic and flavonoids, which gives it the properties to help with inflammation and to be sterile. The Rosemarinic acid helps in cases of poisoning, and the Rosemarol is anti-oxidant. The plant also has an insect repellent characteristic. It is noted that insects are expelled from plants near the rosemary plant.[4]

Trichomonas vaginalis is as an example of urinary whips [2]. It spreads all over the world and has phenotypic qualities and life cycle. The feeding phase is characterized by its pear or elliptic form and may be ovoid. Its length ranges from $7-23 \mathrm{~m}$ and its width is $6.5-7.5 \mathrm{~m}$. The parasite has a short wavy membrane. Chromatin granules in the nucleus are uniformly distributed and the cytoplasm contains a large number of granules that abound around the rib and axial region. The cellular mouth is located near the front end of the opposite side of the membrane and is unclear [5]. The parasite reproduces by simple longitudinal division. There is no polycystic phase of this parasite [3]. There are five whips, four of which are free and the fifth runs with the wavy membrane. The parasite lives in the vaginal area in females and the prostate glands in males. The parasite usually feeds on the surface of the vaginal mucosa, gobbling up bacteria and leukocytes, preferring a basal or slightly acidic medium.

Candida albicans is a genus of yeasts and is the most common cause of fungal infections worldwide.[1] Many species are harmless commensals or endosymbionts of hosts including humans; however, when mucosal barriers are disrupted or the immune system is compromised they can invade and cause disease, known as an opportunistic infection. [15] Candida is located on most of the mucosal surfaces and mainly the gastrointestinal tract, along with the skin. [16] Candida albicans is the most commonly isolated species and can cause infections (candidiasis or thrush) in humans and other animals. In winemaking, some species of Candida can potentially spoil wines.[6]

This study was carried out to study the effectiveness of chewing gum towards Candida fungus through the preparation of water and alcohol extracts for this substance and therefore its use in alternative treatment for diseases associated with this fungus.[4]

\section{Materials and methods}

\subsection{Materials:}

Rosmarinus officinalis was obtained from the local market of the city of Kirkuk - Kirkuk - Iraq The sample of Candida albicans and trichomoniasis was obtained from the Faculty of Science, University of Kirkuk.

\subsection{Preparation of water extracts}

The extract was prepared with $50 \mathrm{~g}$ of Rosmarinus officinalis in $160 \mathrm{ml}$ of distilled water using the Blender[17]. Then the mixture was moved into a magnetic stirrer for 60 minutes, then put in the fridge for 24 hours for soaking. It was then filtered after using the gauze, then the coolant was centrifuged for 15 minutes and then dried by the drying device - lyophilizer. Without this device, sunlight can be used. The samples are preserved after drying with a tight lid in conditions until needed for use [14].

\subsection{Preparation of alcoholic extract}

The solution was prepared by dissolving $50 \mathrm{~g}$ in $250 \mathrm{ml}$ of ethanol alcohol after it is placed in the rotary vaporation electrothermal rotary device then dried and placed in sealed glass bottles until it is used[11].

\subsection{Preparation of different concentrations of extract}

Amounts of $0.1 \mathrm{~g}, 0.2 \mathrm{~g}$ and $0.4 \mathrm{~g}$ of water were extracted and dissolved in $2 \mathrm{ml}$ of solvent to prepare the concentrations in the water extract. The filters with a diameter of 0.45 microns were used [17][18]. In the case of alcohol extract, Dimethyl sulfoxide was used as a solvent and references sterilizer. This was extracted in a 62-degree pasteurized manner for 15 minutes[5]. 


\subsection{The test of inhibitory effectiveness}

The method of Kirby-Bauer was adopted for this test. The method involves making small circles of filter paper with a $0.6 \mathrm{~mm}$ diameter [6] The small filter leaves are placed in different concentrations of both alcohol and water extracts and then left for a full day for saturation. After that, we incubated 3 dishes for half an hour to imbibe. Next, the discs of the filter paper of $0.6 \mathrm{~mm}$ diameter were filled with what had been immersed in these extracts which incubated on sabouraud dextrose agar These tablets were then confirmed by the sterile forceps of the Candida fungus and incubated at $37^{\circ} \mathrm{C}$ for 24 hours after the completion of the incubation. The diameters were observed and measured around the tablets saturated with the extract[7].

\section{Results and discussion}

To isolate the parasite, a drop of vaginal secretions was taken and mixed with the physiological solution. It was put on a glass slide, covered and examined under a microscope with a force of $10 \mathrm{x}$ and then at a strength of 40X. The parasite was distinguished through the movement of the anterior flagella as well as the ripple membrane between epithelial cells[12]

\subsection{The method used to incubate parasites}

Vaginal trichomoniasis parasites were cultivated in the medium. Diamonds are prepared for every 100 $\mathrm{ml}$ of distilled water and consist of the following materials shown in Table 1 [8]

Table 1 shows materials used to incubate parasites

\begin{tabular}{|l|l|}
\hline Materials & Quantity \\
\hline Tryptone soya broth & $2 \mathrm{gm}$ \\
\hline Yeast extract & $1 \mathrm{gm}$ \\
\hline D-Maltose & $0.5 \mathrm{gm}$ \\
\hline L- Ascorbic acid & $0.02 \mathrm{gm}$ \\
\hline Agar & $0.05 \mathrm{gm}$ \\
\hline Distilled water & $90 \mathrm{~cm}^{3}$ \\
\hline Inhibited human plasma & $10 \mathrm{~cm}^{3}$ \\
\hline Stryptomycin sulphate & $1 \mathrm{gm}$ \\
\hline Nystatine & 500000 \\
\hline
\end{tabular}

These materials were weighed and dissolved in distilled water and placed on the magnetic motor device for an hour, and the solution was filtered using Whatman filter paper number 2. To get rid of the insoluble residue, the acid function was set at 6.2 and made sterile with the sterilized device at a temperature of $121^{\circ} \mathrm{C}$ for 15 minutes [7].

\subsubsection{Plasma source}

Due to the difficulty in obtaining large quantities of sterilized human blood serum, it was modified using human blood plasma type $(\mathrm{O})$ from the blood banks of the hospitals in the city of Kirkuk[8].

\subsubsection{Preparation of complete medium}

Plasma was added to the medium after an inactivation inhibition was applied by placing the plasma in sterile containers tightly sealed in a water bath at a temperature of $56^{\circ} \mathrm{C}$ for 30 minutes at a rate of $10 \%$. McCanty vials type glass bottles were used with a capacity of $25 \mathrm{~cm} 3$ at a rate of $5 \mathrm{~cm} 3$ for each vial under sterile conditions to prevent contamination. The lack of contamination of the medium with bacteria or fungi[9]

\subsubsection{Growth of parasites}

Parasites of the vaginal tremors were vaccinated with the addition of $0.1 \mathrm{~cm} 3$ of the positive culture and were free from contamination after 3 days, i.e. through the logarithmic phase of growth in the glass bottles containing $4.9 \mathrm{~cm} 3$ from the new agricultural medium. The transplant counted an initial $1 * 10^{5}$ cells and under sterile conditions, after which the bottles were incubated at a temperature of 37C[12]. 


\subsubsection{Isolation and diagnosis}

The current study demonstrated its yield to the isolation of Candida albicans by some agricultural and microscopic characteristics, as follows:

The growing colonies appeared in the centre of the saproid dextrose agar in the form of circular colonies [10]. The result was what the researchers Singh et al. found in 2013 which was the appearance of colonies of cream colour, glossy smooth and circular to provide appropriate transplant conditions as shown in Figure 2

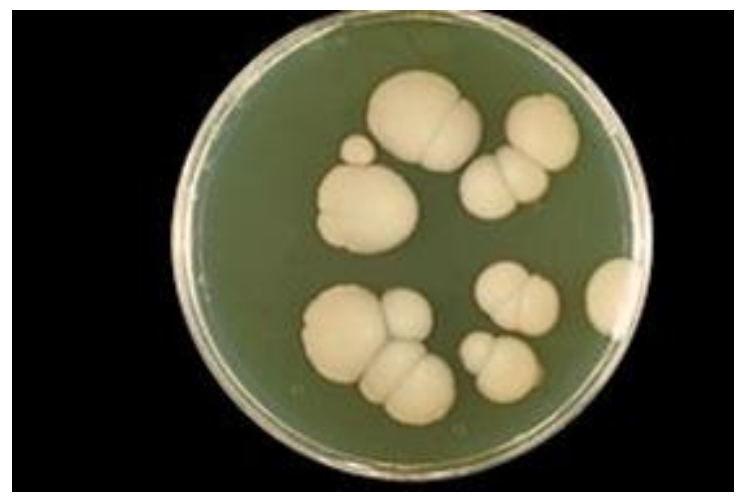

Figure 2 shows the growth of a type of Candida albicans on the SDA medium at a temperature of $37^{\circ} \mathrm{C}$ for 7 days

The isolated sample gave positive reaction results for the gram stain, where oval cells appeared spherical, and this result is consistent with what Sultan et al. found for the year 2018 which was the appearance of the cells in violet colour [13] as a result of the retention of the peptidoglycan layer in the cell wall of this pigment.[9]

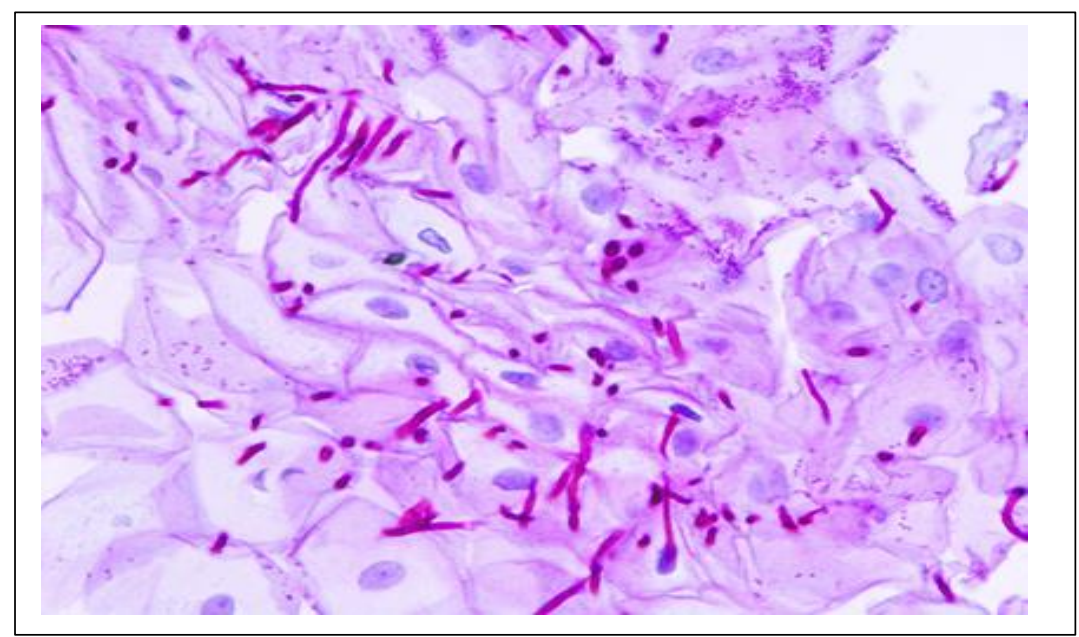

Figure 3 Candida albicans fungi cells stained with gram stain Microbial tube formation

The results showed that the sample is due to Candida albicans by forming a bacterial tube when incubated at a temperature of $37^{\circ} \mathrm{C}$ at 0.5 for 2-3 hours of human serum and these results are consistent with Sultan et al. in 2018 who demonstrated that only the type of Candida albicans can form a bacterial tube in this test, with the presence of the serum catalyst that works on its formation around the yeast cell. The bacterial tube plays an important role in the process of penetration of the layer of epithelial cells lining the body and tissues down to the blood. It is believed that it is necessary for the development of yeast [13][12] 
Table (1) shows the inhibitory effect increases by increasing the concentration of the Rosmarinus officinalis water extract on trichomonas vaginalis

\begin{tabular}{|l|l|l|l|l|}
\hline $\begin{array}{l}\text { Aqueous extract } \\
\text { concentration }\end{array}$ & $\begin{array}{l}\text { At the time of } \\
\text { cultivation }\end{array}$ & Hour1 & Hour2 & Hour3 \\
\hline $\begin{array}{l}\text { D.W and } \\
\text { suitable } \\
\text { condition }\end{array}$ & $\begin{array}{l}\text { Live with } \\
\text { mobility }\end{array}$ & $\begin{array}{l}\text { Live with } \\
\text { mobility }\end{array}$ & $\begin{array}{l}\text { Live with } \\
\text { mobility }\end{array}$ & $\begin{array}{l}\text { Live with } \\
\text { mobility }\end{array}$ \\
\hline $100 \mathrm{mg} / \mathrm{ml}$ & $\begin{array}{l}\text { Live with } \\
\text { mobility }\end{array}$ & $\begin{array}{l}\text { Live with } \\
\text { low mobility }\end{array}$ & $\begin{array}{l}\text { Spherical } \\
\text { and inactive }\end{array}$ & $\begin{array}{l}\text { Dead and } \\
\text { without walls }\end{array}$ \\
\hline $200 \mathrm{mg} / \mathrm{ml}$ & $\begin{array}{l}\text { Live with } \\
\text { mobility }\end{array}$ & $\begin{array}{l}\text { Spherical } \\
\text { and inactive }\end{array}$ & $\begin{array}{l}\text { Dead and } \\
\text { without walls }\end{array}$ & - \\
\hline $400 \mathrm{mg} / \mathrm{ml}$ & $\begin{array}{l}\text { Live with } \\
\text { low mobility }\end{array}$ & $\begin{array}{l}\text { Spherical } \\
\text { and inactive }\end{array}$ & - & - \\
\hline
\end{tabular}

It is clear from Table 1 that there is an adverse effect of the aqueous extract of the rosemary plant inhibited in the parasite's movement and this is consistent with many researchers who have proven that the water extracts influence the growth of some types of microorganisms such as intestinal coliform bacteria and E.coli $[14]$.

Table (2) shows that the inhibitory effect increases by increasing the concentration of the Rosmarinus officinalis alcoholic extract on trichomonas vaginalis

\begin{tabular}{|l|l|l|l|l|}
\hline $\begin{array}{l}\text { Aqueous } \\
\text { concentration }\end{array}$ & At the time of cultivation & Hour1 & Hour2 & Hour3 \\
\hline $\begin{array}{l}\text { D.W and suitable } \\
\text { condition }\end{array}$ & Live with mobility & $\begin{array}{l}\text { Live with } \\
\text { mobility }\end{array}$ & $\begin{array}{l}\text { Live with } \\
\text { mobility }\end{array}$ & $\begin{array}{l}\text { Live with } \\
\text { mobility }\end{array}$ \\
\hline $0.1 \mathrm{mg} / \mathrm{ml}$ & Spherical and inactive & $\begin{array}{l}\text { Dead and } \\
\text { without walls }\end{array}$ & - & - \\
\hline $0.01 \mathrm{mg} / \mathrm{ml}$ & Spherical and inactive & $\begin{array}{l}\text { Spherical and } \\
\text { inactive }\end{array}$ & - & - \\
\hline $0.001 \mathrm{mg} / \mathrm{ml}$ & Live with low mobility & $\begin{array}{l}\text { Spherical and } \\
\text { inactive }\end{array}$ & $\begin{array}{l}\text { Dead and } \\
\text { without walls }\end{array}$ & - \\
\hline
\end{tabular}


From the comparison between the first table and the second table, we notice that the greatest concentration was on alcohol extract $0.1 \mathrm{mg} / \mathrm{ml}$, followed by $0.01 \mathrm{mg} / \mathrm{ml}$ and finally $\mathrm{mg} / \mathrm{ml} 0.001$ which is similar in its effect on the last [16] concentration of the aqueous extract $400 \mathrm{mg} / \mathrm{ml}$. The reason is that the alcohol extract is more efficient than the aqueous extract. This is because ethanol liberates the most active substances present in the plant more than the water that periodically releases tannins and alkaloids that have an antimicrobial effect, including parasites which deposit the proteins associated with cell membranes. The parasite, which affects the process of inserting and removing substances in and out of the cell as well as their formation of complexes with multiple sugars and their effect on enzymes. This is also what Ponder 2found in 2010[15].

The results show the first test of the effective inhibition of the alcoholic and anhydrous extract towards the fungus of Candida albicans within the concentration of $100 \mathrm{mg} / \mathrm{mm}$ where it is noted that the inhibitory effects of the alcohol extract were better compared with the water extract $200 \mathrm{mg} / \mathrm{mm}$ which reflects the best potential for the solvent in the extraction of $400 \mathrm{mg} / \mathrm{mm}$ of active substances. Several studies have proved that Rosmarinus officinalis is preferred. To demonstrate the relationship of concentrations with inhibitory activity, they are explained in the form of the extracts of both alcohol and water extract[18][17] as shown in Table 3 and 4.

Table 3 shows that the inhibitory effect increases by increasing the concentration of the solution in the water extract

\begin{tabular}{|l|l|}
\hline Concentration & Inhibition zone Mm \\
\hline 100 & 7.5 \\
\hline 200 & 9 \\
\hline 400 & 12 \\
\hline
\end{tabular}

Table (3) shows increased inhibitory activity with increased concentrations of an alcohol extract

\begin{tabular}{|l|l|}
\hline Concentration & Inhibition zone Mm \\
\hline 0.1 & $9 \mathrm{~mm}$ \\
\hline 0.2 & $11 \mathrm{~mm}$ \\
\hline 0.4 & $13 \mathrm{~mm}$ \\
\hline
\end{tabular}


Table 3 shows that there is a clear inhibition of the alcoholic extract of the Rose Mary plant higher than the aqueous extract of the same plant and the effect was a direct relationship, that is, the greater the concentration, the greater the diameter of the inhibition because alcohol works to dissolve the active substance more than water and this is consistent with many researchers. Those who emphasized that ethanol extracts contain active substances, the most prominent of which are phenolic compounds that have an anti-fungal, bacterial, and parasitic effect as the aromatic ring in these compounds contain a hydroxyl group that tends to form a hydrogen atom with the active side from now enzimat and thus change the sizes of these enzymes and change their properties [18]. Consequently, it is not effective in the cell, leading to stopping certain vital pathways in the cell leading to stopping its growth or death, as the protein compounds may work to denote the protein inside the cell [19]. 


\section{References:}

[1] Alonso, Jorge. Tratado de Fitofármacos y Nutracéuticos. Barcelona Corpus, p:927-30. (2014)

[2] Abarca, M. L.; Brgulat, M. R.; Burguera, M. T.; Cabanes, F. J. Comparison of some screening methods for aflatoxigenic moulds, Mycopathologia, 104, 75 - 79(2017).

[3] Aruoma, O. I., Halliwell, B., Aeschbach, R., \& Loliger, J. Antioxidant and pro-oxidant properties of active rosemary constituents: carnosol and carnosic acid. Xenobiotica, 22(2), 257-268(2015).

[4] Basaga, H., Tekkaya, C., \& Acitel, F.. Antioxidative and free radical scavenging properties of rosemary extract. Lebensmittel -Wissenschaft und Technologie, 30(1), 105-108 (2017)

[5] Brickell. C. The RHS Gardener's Encyclopedia of Plants and Flowers, Dorling Kindersley Publishers (2018).

[6]Campo, J., Amiot, M., Nguyen, C. The antimicrobial effect of rosemary extracts. Journal of Food Protection; 63:1359-1368. (2010)

[7] De Castro1, M.F.P.M.; Bragagnolo, N.; de Toledo Valentini1, S.R. The relationship between fungi growth and aflatoxin production with ergosterol content of corn grains, Brazilian Journal of Microbiology, 33:22-26 (2012)

[8] Duke. J. A.; Yensu. E. S. Medicinal Plants of China, Reference Publications, Inc. (2014)

[9] Eaton, D. L.; Gallagher, E... Mechanism of aflatoxin carcinogenesis, Annual Review of Pharmacology and Toxicology, 34, 135 - 172(2016)

[10] Hasan, H. AFungicide inhibition of aflatoxins, diacetoxyscirpenol and zearalenone production, Folia Microbiol, 38(4): 295-8 . (2013)

[11] Hitokoto, H.; Morozumi, S.; Wauke, T.; Sakai, S.; Kurata, H. (2016). Mycotoxin production of fungi on commercial foods, Mycotoxins, Pathotox Publishers, Inc., Chicago, USA

[12] Holtom. J. and Hylton. W, Complete Guide to Herbs, Rodale Press. (2014).

[13] Elaldory M., Ali F. AND Sultan S., "2018", "Effective of Watery and Alcoholic Extract of Frankincense on the Candida Albicans Fungus", international journal of pharmaceutical research \& allied sciences issue 7(3), p.p.5662.

[14] Sultan S. Saady A., Elrzogy M.,"2018", "A Comparative Study of the Effect of Alcoholic Extract of Turmeric Plant in Inhibiting the Growth of Candida an Albicans", International Journal of Engineering \& Technology, issue 7(4.37),p.p.12-16

[15] Ponder.E.K, Kourkoumpetis TK, Livanis G, Peleg AY, Mylonakis E. "Statin therapy and decreased incidence of positive Candida cultures among patients with type 2 diabetes mellitus undergoing gastrointestinal surgery". Mayo Clin. Proc. 85 (12): 1073-9. DOI:10.4065/mcp.2010.0447. PMC 2996154. PMID 21123633. (2010)

[16] a $b c d$ Enfert C, Hube B (editors). Candida: Comparative and Functional Genomics. Caister Academic Press. ISBN 978-1-904455-13-4. (2017) 